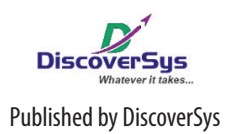

Published by DiscoverSys

\section{Perception of disaster preparedness and participation in training are associated with disaster preparedness among health workers}

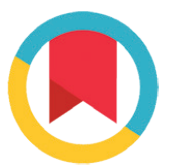

CrossMark

I Made Dwie Pradnya Susila, ${ }^{1 *}$ Pande Putu Januraga, ${ }^{2}$ Ni Wayan Arya Utami ${ }^{2}$

\title{
ABSTRACT
}

Background and purpose: Disaster preparedness is crucial for health workers in order to provide relief to communities affected by disasters quickly and precisely. However currently there are only few health workers who are prepared to face disasters. This study aims to determine the association between knowledge in disaster management, perception of disaster preparedness, participation in training and experience in disaster management with disaster preparedness in health workers.

Methods: A cross sectional survey was conducted among health workers at Petang and Abiansemal public health centres (PHCs). Of the six PHCs in Petang and Abiansemal Sub-districts, four were randomly selected consisting of one PHC in Petang Sub-district and three PHCs in Abiansemal Sub-district. All health workers (271 people) in the four PHCs were selected as respondents. Individual face-to-face interviews were conducted by the first author during April 2018 in the workplaces of each respondent using a pre-tested questionnaire. Data collected consisted of socio-demographic characteristics, knowledge in disaster management, perceptions of disaster preparedness, participation in training, experiences in disaster management and disaster preparedness. Questions consisted of three components namely knowledge in disaster management (12 items), perception of disaster preparedness ( 32 items) and disaster preparedness ( 25 items). Bivariate analysis was conducted with chi square test and multivariate analysis with binary logistic regression to determine the association between knowledge, perception, participation in training and experience in disaster management with disaster preparedness.

Results: The results showed that $70.9 \%$ of respondents had attended disaster training, $40.6 \%$ had good knowledge, $24.7 \%$ had participated in disaster management and $49.1 \%$ had a high level of disaster preparedness. The variables significantly associated with disaster preparedness were perceptions of disaster preparedness ( $A 0 R=6.40$; 95\% Cl: 3.71-10.99) and participation in disaster training ( $A 0 R=2.68$; 95\%(l: 1.44-4.97).

Conclusion: Disaster preparedness among PHC health workers remains low. Perception of disaster preparedness and participation in training are significantly associated with disaster preparedness. Continuous training is needed to increase disaster preparedness among health workers.
${ }^{1}$ Bina Usada Health Institute, Bali Province,

${ }^{2}$ Department of Public Health and Preventive Medicine, Faculty of Medicine, Udayana University

${ }^{*}$ Correspondence to:

I Made Dwie Pradnya Susila, Bina Usada Health Institute, Bali Province, dwiepradnya@gmail.com
Keywords: disaster preparedness, perception of disaster preparedness, participation in training, health workers

Cite This Article: Susila, I.M.D.P., Januraga, P.P., Utami, N.W.A. 2019. Perception of disaster preparedness and participation in training are associated with disaster preparedness among health workers. Public Health and Preventive Medicine Archive 7(1): 8-13. D01:10.15562/phpma. v7i1.186

\section{INTRODUCTION}

Natural disasters occur frequently in Indonesia and in 2016-2017 these were dominated by hydrometeorological disasters (tornadoes, floods and landslides). Nationally, natural disasters in 2017 have increased to reach $38 \%$ compared to $2015,{ }^{1,2}$ while natural disasters in Bali Province increased by $40 \%$ in 2017 compared to 2016, including the Mount Agung volcanic eruption. Badung District has been frequently affected by natural disasters and disaster preparedness in this area is crucial considering Badung District is the main entrance point for tourists to Bali and other Indonesian provinces. ${ }^{2,3}$ National Disaster Management Act Number 24 of 2007 states that everyone, including health workers, has an obligation to carry out disaster management. ${ }^{4}$ In addition, in accordance with National Health Workers Act Number 36 of
2014, health workers must have the knowledge and ability to provide first aid in post-disaster recovery process. $^{5}$

Previous studies mostly conducted among nurses and residents of particular areas. Those studies show that factors associated with disaster preparedness were length of work, ${ }^{6-9}$ age, ${ }^{7,10}$ previous disaster experience, ${ }^{6,8}$ experience in disaster evacuation sites, ${ }^{6,8}$ emergency training, ${ }^{6,11}$ self-regulation (perception) ${ }^{10,12}$ and health services climate. ${ }^{8}$ Studies also indicated that nurses feel unprepared in disaster situations, lack of confidence and consider themselves and their institutions to be less experienced in disaster conditions. ${ }^{6,13}$ Another study shows that only $32 \%$ of healthcare providers (physicians, nurses, and pharmacists) have bioterrorism disaster response competencies, which are 
caused by a lack of emergency disaster training and experience in dealing with disasters. ${ }^{14}$

Studies on factors related to disaster preparedness for health workers other than nurses has not been widely published. This study aims to determine the association of knowledge in disaster management, perception of disaster preparedness, participation in training and experience in disaster management with disaster preparedness among health workers.

\section{METHODS}

A cross-sectional survey was conducted among health workers at PHCs in Petang and Abiansemal Sub-districts. Those two sub-districts have experienced relatively more natural disasters than the others in Badung District. Of the six PHCs in those two sub-districts, four were randomly selected consisting of one PHC in Petang (Petang I PHC) and three PHCs in Abiansemal (Abiansemal I, II and III PHCs). All health workers (271 people) in the four PHCs were selected as respondents. Individual faceto-face interviews were conducted by first author during April 2018 in the workplaces of each respondent using a questionnaire that had been tested previously on 30 health workers at the Baturiti I PHC. Each respondent had received an information sheet and signed an informed consent before the interview.

The disaster preparedness questionnaire consisted of 25 items and adopted the Emergency Preparedness Information Questionnaire (EPIQ) which had been translated into Indonesian. ${ }^{8,15}$ Questions about disaster experience refer to the concepts developed by Baack \& Alfred, ${ }^{6}$ namely participation in disaster training, previous disaster experiences, and experience in refugee camps consisting of 12 items of questions. The questionnaire on disaster management knowledge was compiled in reference to National Disaster Management Act Number 24 of 2007 which consisted of 12 statements, including types of disasters, causes of disasters and disaster management. ${ }^{4}$ The disaster preparedness perceptions questionnaire consisted of 32 items in reference to the Health Belief Model, ${ }^{16}$ namely aspects of susceptibility, severity, benefits, barriers and self-efficacy. In the questionnaire on disaster preparedness and disaster preparedness perceptions, each statement consisted of four options namely "strongly agree", "agree", "disagree", "strongly disagree". The option of "strongly agree" is scored four, "agree" is scored three, "disagree" is scored two and "strongly disagree" is scored one on a positive statement and vice versa on a negative statement. In the disaster knowledge questionnaire, each statement consisted of two options that are "correct" and "incorrect". The option of "correct" is scored one and "incorrect" is scored zero on a positive statement and vice versa in the negative statement. Knowledge is categorized into "good" $(\geq 8)$ and "poor" $(<8)$ with the median score as the cut-off point. Perceptions are categorized into good $(\geq 80)$ and poor $(<80)$ with the median score as the cut-off point. Disaster preparedness is categorized into high $(\geq 75)$ and low $(<75)$ with the median score as the cut-off point.

Bivariate analysis was carried out with chi square test and multivariate analysis with binary logistic regression to determine the association between knowledge in disaster management, perception of disaster preparedness, participation in training and experience in disaster management with disaster preparedness. This study has been approved by the Ethics Committee of the Faculty of Medicine, Udayana University/Sanglah General Hospital in Denpasar on April 16, 2018.

\section{RESULTS}

Table 1 shows the characteristics of respondents based on age, gender, education and duration of work. About half of the health workers are $\leq 30$ years old, mostly female, hold a diploma degree and $0-5$ years working experience. Table 2 shows the proportion of respondents based on disaster preparedness experience which consists of participation in training, previous disaster experience and experience in refugee camps. Most health workers have attended disaster training, most of which attended the Basic Life Support Training. However, the proportion of respondents who have had experience working in disaster management is very low, namely $7.0 \%$ and experience in refugee camps is $24.7 \%$. More than half of the respondents had insufficient knowledge in disaster management, perceptions of disaster preparedness, and disaster preparedness.

In Table 3, the association between independent variables and disaster preparedness is presented. Age, sex, education, length of work, type of health worker status, previous disaster experience, experience in refugee camps and knowledge of disasters were not found to have a significant association with disaster preparedness. Variables that have a significant association with disaster preparedness are participation in training and perception of disaster preparedness. A total of 106 respondents (55.2\%) who had attended training had high preparedness and 27 respondents (34.2\%) who had never attended training had a high preparedness $(\mathrm{p}<0.01)$. A total of 94 respondents (71.2\%) with good perceptions of disaster preparedness had high preparedness and as many as 39 respondents (28.1\%) with low 
Table 1 Characteristics of respondents

\begin{tabular}{|c|c|c|}
\hline Characteristics & $\mathbf{n}$ & Proportion (\%) \\
\hline \multicolumn{3}{|l|}{ Age (years) } \\
\hline$\leq 30$ & 139 & 51.3 \\
\hline$>30$ & 132 & 48.7 \\
\hline \multicolumn{3}{|l|}{ Gender } \\
\hline Female & 224 & 82.7 \\
\hline Male & 47 & 17.3 \\
\hline \multicolumn{3}{|l|}{ Education } \\
\hline Three years diploma & 196 & 72.3 \\
\hline Four years diploma & 3 & 1.1 \\
\hline Graduate & 71 & 26.2 \\
\hline Postgraduate & 1 & 0.4 \\
\hline \multicolumn{3}{|l|}{ Duration of work (years) } \\
\hline $0-5$ & 135 & 49.8 \\
\hline $6-12$ & 68 & 25.1 \\
\hline$>12$ & 68 & 25.1 \\
\hline \multicolumn{3}{|l|}{ Types of health worker } \\
\hline Midwife & 105 & 38.7 \\
\hline Nurse & 102 & 37.6 \\
\hline Physician & 14 & 5.2 \\
\hline Dentist & 12 & 4.4 \\
\hline Dental nurse & 9 & 3.3 \\
\hline Public health workers & 8 & 3.0 \\
\hline Other & 21 & 7.7 \\
\hline Total & 271 & 100 \\
\hline
\end{tabular}

\section{Table 2 Distribution of disaster preparedness and disaster experiences}

\begin{tabular}{lcc}
\hline Variables & $\mathbf{n}$ & Proportion (\%) \\
\hline Participation in training & & \\
Ever (type of training) & 192 & 70.8 \\
First aid & 145 & 53.5 \\
Basic Trauma and Cardiac Life Support (BTCLS) & 30 & 11.1 \\
Emergency first aid & 6 & 2.2 \\
Disaster Management & 5 & 1.8 \\
Other & 6 & 1.9 \\
Never & 79 & 29.2 \\
Prior disaster experience & & \\
Yes & 19 & 7.0 \\
No & 252 & 93.0 \\
Experience in refugee camps & & \\
Yes & 67 & 24.7 \\
No & 204 & 75.3 \\
Knowledge in disaster management & & \\
Good & 110 & 40.6 \\
Poor & 161 & 59.4 \\
\hline
\end{tabular}


Table 2 Continue

\begin{tabular}{llc}
\hline Variables & $\mathbf{n}$ & Proportion (\%) \\
\hline Perception of disaster preparedness & & \\
$\quad$ Good & 132 & 48.7 \\
Poor & 139 & 51.3 \\
Disaster preparedness & & \\
$\quad$ High & 133 & 49.1 \\
Low & 138 & 50.9 \\
Total & 271 & 100 \\
\hline
\end{tabular}

Table 3 Association between variables and disaster preparedness

\begin{tabular}{|c|c|c|c|}
\hline \multirow[b]{3}{*}{ Variables } & \multicolumn{2}{|c|}{ Disaster preparedness } & \multirow[b]{3}{*}{$\mathbf{p}$} \\
\hline & High & Low & \\
\hline & n (\%) & n (\%) & \\
\hline \multicolumn{4}{|l|}{ Age } \\
\hline$\leq 30$ & $63(45.3)$ & $76(54.7)$ & 0.13 \\
\hline$>30$ & $70(53.0)$ & $62(47.0)$ & \\
\hline \multicolumn{4}{|l|}{ Gender } \\
\hline Male & $26(55.3)$ & $21(44.7)$ & 0.22 \\
\hline Female & $107(47.8)$ & $117(52.2)$ & \\
\hline \multicolumn{4}{|l|}{ Education } \\
\hline Diploma & $97(48.7)$ & $102(51.3)$ & 0.48 \\
\hline Graduate and higher & $36(50.0)$ & $36(50.0)$ & \\
\hline \multicolumn{4}{|l|}{ Duration of work (years) } \\
\hline$\leq 6$ & $70(49.3)$ & $72(50.7)$ & 0.52 \\
\hline$>6$ & $63(48.8)$ & $66(51.2)$ & \\
\hline \multicolumn{4}{|l|}{ Type of health worker } \\
\hline Medical & $126(49.8)$ & $127(50.2)$ & 0.26 \\
\hline Non-medical & $7(38.9)$ & $11(61.1)$ & \\
\hline \multicolumn{4}{|l|}{ Participation in training } \\
\hline Yes & $106(55.2)$ & $86(44.8)$ & $<0.01$ \\
\hline No & $27(34.2)$ & $52(65.8)$ & \\
\hline \multicolumn{4}{|l|}{ Prior disaster experience } \\
\hline Yes & $9(47.4)$ & $10(52.6)$ & 0.53 \\
\hline No & $124(49.2)$ & $128(50.8)$ & \\
\hline \multicolumn{4}{|c|}{ Experience in refugee camps } \\
\hline Yes & $32(47.8)$ & $35(52.2)$ & 0.46 \\
\hline No & $101(49.5)$ & $103(50.5)$ & \\
\hline \multicolumn{4}{|c|}{ Knowledge in disaster management } \\
\hline Good & $53(48.2)$ & $57(51.8)$ & 0.45 \\
\hline Poor & $80(49.7)$ & $81(50.3)$ & \\
\hline \multicolumn{4}{|c|}{ Perception of disasters preparedness } \\
\hline Good & $94(71.2)$ & $38(28.8)$ & $<0.01$ \\
\hline Poor & $39(28.1)$ & $100(71.9)$ & \\
\hline
\end{tabular}


Table 4 Adjusted OR of age, gender, participation in training and perception of disaster preparedness

\begin{tabular}{lccc}
\hline Variables & AOR & $\mathbf{9 5 \% C l}$ & p \\
\hline Age & 1.03 & $0.99-1.06$ & 0.11 \\
Gender & 1.01 & $0.49-2.10$ & 0.98 \\
Participation in training & 2.68 & $1.44-4.97$ & $<0.01$ \\
Perception of disasters preparedness & 6.40 & $3.71-11.03$ & $<0.01$ \\
\hline
\end{tabular}

perceptions had high preparedness $(\mathrm{p}<0.01)$. Four variables with $\mathrm{p}$ values $<0.25$ in bivariate analysis were included in the multivariate analysis. Table 4 presents adjusted OR for variables that are significantly associated with disaster preparedness, namely the perception of disaster preparedness $(\mathrm{AOR}=6.40$; 95\%CI: 3.71-10.99) and participation in training $(\mathrm{AOR}=2.68 ; 95 \% \mathrm{CI}: 1.44-4.97)$

\section{DISCUSSION}

The results of our study indicate that the proportion of respondents who have had experience working in disaster management is very low at $7.0 \%$ and the experience in refugee camps is $24.7 \%$. This is likely because the opportunity for health workers in the Petang and Abiansemal PHCs to be assigned to disaster management is very limited. In this study it was also found that only about half of the respondents had good knowledge in disaster management, perceptions and preparedness. This is likely because there are about $29 \%$ of respondents never participated in training and may also related to the lack of post-training simulations. Other studies conducted in Indonesia revealed that simulations can improve respondents' knowledge and skills so that capacity in disaster preparedness increases. ${ }^{17,18}$ Studies in other countries show that training accompanied by simulations significantly increases knowledge but does not improve perceptions of disaster preparedness. ${ }^{19}$ Low disaster preparedness is also reported in other countries. A study in Hongkong showed that disaster preparedness of health workers was still low, with only $38.4 \%$ of nurses acting in accordance with the protocol in the event of a disaster. ${ }^{11}$

In our study the type of training that most respondents participated in was first aid and very little about basic trauma cardiac life support (BTCLS). Training in BTCLS currently only provided for services providers in the emergency unit in hospitals. ${ }^{20}$ Ministry of Health Act Number 75 Year 2014 regarding PHCs also does not require disaster preparedness training for health workers at PHCs. ${ }^{21}$ Because health workers in PHCs are at the frontline to respond disasters in their working areas, it is crucial for developing policy and regulation in order to increase disaster preparedness among them.

In our study, the participation in disaster preparedness training was significantly related to disaster preparedness. Other study conducted on nursing students in Indonesia shows that disaster training can increase disaster preparedness knowledge and abilities. ${ }^{22}$ The results of similar studies with nurses in Indonesia also shows that participation in emergency training was able to improve clinical skills for the care of tsunami patients. ${ }^{23}$ However, another study shows that disaster training can only improve the knowledge of hospital emergency staff but not on disaster preparedness capabilities. ${ }^{24}$

In our study disaster's preparedness perception were also found to be significantly related to disaster preparedness. This is probably because the respondents felt that their areas were at risk of disasters. Studies in other countries also show that perceived susceptibility have a significant association with disaster preparedness. ${ }^{10,12,25}$ In addition, another study stated that previous disaster experiences had an association with perceptions of susceptibility so that it would be able to improve disaster preparedness. ${ }^{26}$

Our study was only carried out among health workers in Petang and Abiansemal PHCs which located in a rural higher land areas with a high risk of landslides but lower risk of tsunamis and mount eruptions, therefore the generalization of the results into different contexts need to be taken in caution.

\section{CONCLUSION}

About half of respondents in this study have low disaster preparedness. Disaster preparedness for health workers is found to be associated with perceptions of disaster preparedness and participation in training. To improve disaster preparedness, ongoing disaster management training and simulations are needed.

\section{ACKNOWLEDGEMENT}

We would like to thank the Ministry of Research, Technology and Higher Education for providing 
scholarships for this study. We would also like to thank the Badung Health Office and Head of the Petang and Abiansemal PHCs for providing support to this study. Finally, we would like to thank all health workers who participated in this study.

\section{REFERENCES}

1. National Agency for Disaster Countermeasure. Capaian kinerja 2016 [Performance achievement 2016]. Jakarta; 2016.

2. National Agency for Disaster Countermeasure. Data informasi bencana Indonesia [Indonesia disaster information data] [Internet]. 2017. Available from: http://dibi.bnpb. go.id/dibi/. Accessed August 12, 2017

3. Statistics of Bali Province. Jumlah wisatawan mancanegara ke Provinsi Bali per bulan, 2011-2017 [Number of foreign tourist to Bali Province per month, 2011-2017] [Internet]. 2017. Available from: https://bali.bps.go.id/linkTableDinamis/view/id/64. Accessed August 12, 2017

4. The President of Republic of Indonesia. Undang-undang No. 24 Tahun 2007 tentang Penanggulangan Bencana [Law No. 24 year 2007 on Disaster Management] [Internet]. Jakarta; 2007. Available from: http://www.peraturan.go.id/ search/download/11e44c4ed 9324200837 e313231373036. html. Accessed August 12, 2017

5. The President of Republic of Indonesia. Undang-undang No. 36 Tahun 2014 tentang Tenaga Kesehatan [Law No. 36 year 2014 on Health Workers] [Internet]. Jakarta; 2014. Available from: http://hukor.kemkes.go.id/uploads/produk_hukum/UU No. 36 Th 2014 ttg Tenaga Kesehatan.pdf. Accessed August 12, 2017

6. Baack S, Alfred D. Nurses' preparedness and perceived competence in managing disasters. Journal of Nursing Scholarship. 2013;45(3):281-7.

7. Ogedegbe C, Nyirenda T, DelMoro G, Yamin E, Feldman J. Health care workers and disaster preparedness: barriers to and facilitators of willingness to respond. International Journal of Emergency Medicine. 2012;5(1):29.

8. Wahidah DA, Rondhianto, Hakam M. Faktor-faktor yang mempengaruhi kesiapsiagaan perawat dalam menghadapi bencana banjir di Kecamatan Gumukmas Kabupaten Jember [Factors affecting nurse preparedness in facing flood disaster in Gumukmas Subdistrict, Jember District]. Jurnal Pustaka Kesehatan. 2016; 4(3):568-74.

9. Magnaye B, Muñoz MSLM, Muñoz MAF, Muñoz RG V, Muro JHM. The role, preparedness and management of nurses during disasters. International Scientific Research Journal. 2011;3(4):269-94.

10. Sattler DN, Kaiser CF, Hittner JB. Disaster preparedness: relationships among prior experience, personal characteristics and distress. Journal of Applied Social Psychology. 2000;30(7):1396-420.

11. Fung OWM, Loke AY, Lai CKY. Disaster preparedness among Hong Kong nurses. Journal of Advanced Nursing. 2008;62(6):698-703

12. Miceli R, Sotgiu I, Settanni M. Disaster preparedness and perception of flood risk: A study in an alpine valley in Italy. Journal of Environmental Psychology. 2008;28(2):164-73.

13. O'Sullivan TL, Dow D, Turner MC, Lemyre L, Corneil W, Krewski D, et al. Disaster and emergency management: Canadian nurses' perceptions of preparedness on hospital front lines. Prehospital and Disaster Medicine. 2008;23(3):S11-8.

14. Crane JS, McCluskey JD, Johnson GT, Harbison RD. Assessment of community healthcare providers ability and willingness to respond to emergencies resulting from bioterrorist attacks. Journal of Emergencies, Trauma and Shock. 2010;3(1):13.
15. Wisniewski R, Dennik-Champion G, Peltier JW. Emergency preparedness competencies: assessing nurses' educational needs. Journal of Nursing Administration. 2004;34(10):475-80.

16. Rosenstock IM. Historical origins of the Health Belief Model. Health education monographs.1974;2(4):328-35.

17. Purnamasari I. Pengaruh simulasi bencana terhadap kesiapsiagaan pramuka dalam menghadapi bencana banjir di SMP Negeri 3 Mojolaban Kecamatan Mojolaban Kabupaten Sukoharjo [The effect of disaster simulation on scout preparedness in facing flood disaster in Mojolaban Junior High School, Mojolaban Sub-District, Sukoharjo District]. Muhammadiyah University, Surakarta; 2013.

18. Sari NP. Peran simulasi bencana terhadap kesiapsiagaan siswa Kelas VII dalam menghadapi bencana gempa bumi di MTs Negeri Gantiwarno Kecamatan Gantiwarno Kabupaten Klaten [The role of disaster simulation on preparedness of student $7^{\text {th }}$ class in facing earthquake disaster at MTs Gantiwarno, Gantiwarno Sub-District, Klaten District]. Muhammadiyah University, Surakarta; 2014.

19. Bartley BH, Stella JB, Walsh LD. What a disaster?! Assessing utility of simulated disaster exercise and educational process for improving hospital preparedness. Prehospital and disaster medicine. 2006;21(4):249-55.

20. Ministry of Health of Indonesia. Keputusan Menteri Kesehatan Republik Indonesia No 129/Menkes/SK/ II/2008 tentang Standar Pelayanan Minimal Rumah Sakit [Decree of Ministry of Health of Indonesia No. 129/Menkes/SK/II/2008 on Hospital Minimum Service Standards] [Internet]. 2008 p. 1-55. Available from: http://www.pelkesi.or.id/ index.php?option=com_jotloader\&section $=$ files\&task $=$ download \&cid $=16 \_7 \mathrm{c}$ $615 \mathrm{c} 64254 \mathrm{e} 8 \mathrm{~d} 50 \mathrm{eb} 26646 \mathrm{be} 44271 \mathrm{fa} \&$ Itemid $=123$. Accessed July 19, 2017

21. Ministry of Health of Indonesia. Permenkes RI No. 75 Tahun 2014 tentang Puskesmas [Regulation of the Ministry of Health of Indonesia No. 75 year 2014 on Public Health Center] [Internet]. Jakarta; 2014. Available from: http://www.aidsindonesia.or.id/uploads/20141210110659. PMK_No_75_Th_2014_ttg_CHC.pdf. Accessed July 23, 2017

22. Alim S, Kawabata M, Nakazawa M. Evaluation of disaster preparedness training and disaster drill for nursing students. Nurse education today. 2015;35(1):25-31.

23. Husna C, Hatthakit U, Chaowalit A. Emergency training, education and perceived clinical skills for tsunami care among nurses in Banda Aceh, Indonesia. Nurse Media Journal of Nursing. 2011;1(1):75-86.

24. Cotanda CP, Martínez MR, de la Maza VTS, Cubells CL. Impact of a disaster preparedness training programme on health staff. Anales de Pediatría (English Edition). 2016;85(3):149-54.

25. Bradford RA, O'Sullivan JJ, Van der Craats IM, Krywkow J, Rotko P, Aaltonen J, et al. Risk perception-issues for flood management in Europe. Natural hazards and earth system sciences. 2012;12(7):2299-309.

26. Riad JK, Norris FH. Hurricane threat and evacuation intentions: An analysis of risk perception, preparedness, social influence, and resources. 1998; University of Delaware Disaster Research Center.

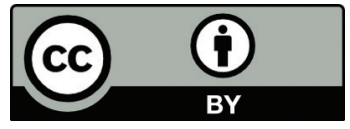

This work is licensed under a Creative Commons Attribution 